\title{
DEVELOPMENTS OF CONSTITUTIONAL JUSTICE IN THE REPUBLIC OF MOLDOVA
}

DOI: 10.47743/rdc-2015-1-0006

Aurel B̆̈IEŞU

Habilitated Doctor, University Professor; Judge, Constitutional Court of the Republic of Moldova

\section{Consecration of constitutional review model. Historical background}

The Constitutional Court of the Republic of Moldova, as a separate body, vested with the constitutional review, is a relatively young institution, as there was nothing similar until the proclamation of the sovereignty and independence of the Republic of Moldova. Changing the political and economic system has resulted in the need to create a legal framework for development towards a democratic, sovereign, independent, unitary and indivisible state, governed by the rule of law, establishing completely new institutions which are totally different from those in the former Soviet province. For the draft Constitution of the Republic of Moldova, the parliamentary and constitutional committees undertook the ideas expressed by the representatives of indigenous doctrine on the need for establishing an independent authority which carries out the constitutional review. Thus, on 23 February 1995 the Constitutional Court was established, the first and sole authority of constitutional jurisdiction in the Republic of Moldova.

The Constitutional Court was designed by the framer, following the kelsenian model, as an authority of constitutional justice, separate from the ordinary court system. The Court is independent from the legislative, executive and judiciary authority, ensuring the principle of separation of powers, as well as the responsibility of the state for the citizen and of the citizen for the state.

The status and powers of the Constitutional Court are directly established in the Constitution. Thus, Title V of the Constitution conferred upon the Constitutional Court the status of sole authority of constitutional jurisdiction in the Republic of Moldova, independent of any other public authority and obeying only the Constitution, being the guarantor for the supremacy of the Constitution (Article 134). Similarly, the Supreme Law expressly regulates its powers (Article 135), its structure (Article 136), the status of constitutional judges (Articles 137, 138 and 139) and the legal value of acts of the Constitutional Court (Article 140). The regulations on the status and activity of the Constitutional Court were subsequently developed by Law no. 317-XIII of 13 December 
1994 on the Constitutional Court and the Constitutional Jurisdiction Code no. 502-XIII of 16 June 1995.

The Constitutional Court operates in compliance with the principles of independence, collegiality, legality and publicity, has financial autonomy and its own budget, separate within the state budget. The law establishes a series of safeguards so as judges shall carry out their powers, the main ones being the independence, immovability and immunity. The Court is composed of six judges, appointed by the branches of power in the state for a six-year term of office, with the right to claim a second term of office. Two judges are appointed by Parliament, two by the Government and two by the Superior Council of Magistracy.

Until a recent ruling of the Court, Article 23 para. (4) of Law no. 317-XIII of 13 December 1994 on the Constitutional Court stated that "the Constitutional Court shall have the right to meet in plenary session only when at least 4 of the judges have been appointed by all competent authorities". In Ruling no. 6 of 16 May 2013, the Court rules that "[...] without challenging the right of the three authorities (legislative, executive and judiciary) to appoint the judges of the Court, [...] the condition established for the appointment of judges by all authorities in order to convene the plenum, if the decision-making quorum required by law exists within the Court, impairs the functionality of the Court and infringes the principle of independence of the Court and of its judges [Articles 134 para. (2), 135 and 137 of the Constitution]. Consequently, the provisions of Article 23 para. (4) of the Law on the Constitutional Court are unconstitutional ${ }^{1}$.

Unlike the common law courts, the Constitutional Court of the Republic of Moldova is a political and jurisdictional public authority which exclusively examines law issues. The main role of the Constitutional Court (but not the sole one) is the constitutional review of the normative acts adopted by Parliament, by the President of the Republic of Moldova and by the Government, as well as of international treaties. As a "negative legislature", the Constitutional Court exercises a supervisory activity designed to inform public authorities whose acts are subject to review and to stop the action of the normative act which does not comply with the Constitution. The decisions of the Court are final and binding, imposing the legal invalidity of the normative act or of its provisions which were declared unconstitutional.

\section{Jurisprudential developments on the constitutional review/competence}

\section{of the Constitutional Court}

As concerns the establishment of its own competence, the Constitutional Court rules that "[...] by virtue of powers established by the Basic Law in order to fulfil the role of guarantor for the supremacy of the Constitution, the Court is the only one vested to

\footnotetext{
1 Decision no. 6 of 16 May 2013 on the constitutional review of Article 23 para. (4) of Law no. 317-XIII of 13 December 1994 on the Constitutional Court (Referral 17a/2013), Official Gazette 119-121/12 of 31 May 2013.
}

REVISTA DE DREPT CONSTITUŢIONAL 
judicially establish the framework for the exercise of its power of constitutional review on the acts attributed to its competence under Article 135 of the Constitution, as indeed it has acted so far. The Court shall examine the object of the challenges brought before it and accordingly settle them in relation to the constitutional values and principles concerned" ${ }^{2}$.

The case-law of the Court on the establishment of its own competence has been developed both in terms of rationae materiae and rationae temporis aspect.

Under rationae materiae aspect, it is worth mentioning the development of the caselaw of the Court regarding the review of individual acts. The Constitutional Court, Having the exclusive right, enshrined in Article 135 para. (1) letter a) of the Constitution, for the exercise of the constitutional review on all resolutions of Parliament, on the decrees of the President of the Republic of Moldova and on the resolutions of the Government, the Court has established its own case-law on the individual acts, which it gradually revised it, in relation to the socio-political and economic situation, to the regulatory framework and to the case-law of the ECHR. The turning point was the Decision no. 10 of 16 April 2010 for the revision of the Constitutional Court's Decision no. 16 of 28 May 1998, "The interpretation of Article 20 of the Constitution", in the wording of the Decision no. 39 of 9 July $2001^{3}$, by which the Court revised its initial approach, according to which the individual administrative acts were not subject to constitutional review. By Decision no. 10 of 16 April 2010, the Court held that "individual administrative acts issued by Parliament, the President of the Republic of Moldova and the Government in the exercise of powers expressly provided by constitutional or legislative rules on the election, appointment and dismissal from public offices of officials, representatives of particular public interest, are subject to constitutional review on the referral of the authorities competent to exercise this right under the aspect of form and procedure for adoption".

In the same vein, by another decision ${ }^{4}$, the Court mentioned that the Constitutional Court judges, the judges of the Supreme Court, the General Prosecutor, the members of the CEC and other State officials, representatives of a particular public interest, appointed for one term of office, cannot be subject to the same treatment as the politicians. They must have certain guarantees from the state in order to actually exercise its term of office.

Subsequently, in line with the new approach, the Constitutional Court review the constitutionality of acts on the revocation from the term of office of a number of dignitaries: cases Muruianu (the President of the Supreme Court of Justice), Urechean (the President of the Court of Auditors), Gurin (the General Prosecutor), Parlicov (the

\footnotetext{
2 Decision no. 9 of 14 February 2014 for the interpretation of Article 135 para. (1) letter a) of the Constitution of the Republic of Moldova (Referral no. 52b/2013), Official Gazette 78-79/9, 1 April 2014.

${ }^{3}$ Official Gazette no. 58-60/9 of 23 April 2010.

${ }^{4}$ Decision no. 29 of 21 December 2010 for the constitutional review of Law no. 95 of 21 May 2010 "Amending and supplementing certain legislative acts", Official Gazette 1-4/1, 7 January 2011.
} 
General Director of the Board of the National Agency for Energy Regulation) in terms of the competence of authority to adopt the act concerned and the adoption procedure.

For the development of this new approach, by a recent decision ${ }^{5}$, the Court stated that "the examination of the procedure for the adoption of the act subject to constitutional control includes both verifying the compliance with the procedure for issuing/adopting the act and verifying the compliance with legal requirements necessary for the appointment/dismissal of the officials".

Developments regarding its rationae temporis competence is also observed in the caselaw of the Court. It should be noted that, until a recent case, the Court performed only the $a$ posteriori review and the acts susceptible for constitutional review were accepted for review only after their entry into force. This approach was based on a limitative interpretation of the concept of "law" within the meaning of Article 135 para. (1) letter a) of the Constitution. By Decision no. 9 of 14 February $2014^{6}$, the Court has changed its approach. Thus, the Court held that the evolutionary interpretation of the powers of the Constitutional Court is that to enable the increase and extension of mechanisms of the constitutional court. Therefore, to restrictively interpret the mentioned fundamental rule in order to limit, remove or reduce the powers of the Constitutional Court would result in its diversion from the purpose of improving the constitutional democracy, pursued by the framer itself. Consequently, the Court held that the exercise of constitutional review on a law, according to Article 135 para. (1) letter a) of the Constitution may intervene both before promulgation and after entry into force by fulfilling the procedures required by law. The constitutional review of laws before promulgation inextricably integrates a legal mechanism likely to contribute to the effective preventive protection of fundamental human rights and freedoms.

\section{Acceptance of international law/European Union}

\section{by constitutional case-law}

The establishment and strengthening of the Republic of Moldova as an independent and democratic state, with the status of international subject of law question the interaction of domestic and international law. The obligation to comply with the international agreements by the Republic of Moldova is enshrined in Article 8 para. (1) of the Constitution, according to which the Republic of Moldova undertakes to comply with the Charter of the United Nations Organization and the treaties to which it is a party, to establish its relations with other states on the universally recognized principles and rules

\footnotetext{
5 Decision no. 22 of 16 July 2015 on the constitutional review of the Resolution of Parliament no. 140 of 3 July 2015 on the appointment of the Advocate of the People for children's rights (Referral no. 31a/2015), 0fficial Gazette no. 241-246/23 of 28 August 2015.

${ }^{6}$ Official Gazette no. 78-79/9 of 1 April 2014.
}

REVISTA DE DREPT CONSTITUŢIONAL 
of international law. At the same time, Article 8 para. (2) of the Constitution provides that "the entry into force of an international treaty containing provisions contrary to the Constitution shall be preceded by review".

The international human rights treaties acquired a special status as they were placed in the hierarchy of normative acts on the same level with the Constitution and having precedence over the domestic law in case of dispute (Article 4 of the Constitution).

In its case-law, the Constitutional Court has regularly invoked such international acts such as the Universal Declaration of Human Rights, the European Convention on for the Protection of Human Rights and Fundamental Freedoms, the International Covenant on Civil and Political Rights and the Covenant on Economic, Social and Cultural Rights, the Convention on the Elimination of All Forms of Discrimination against Women; the Convention concerning Discrimination in Respect of Employment and Occupation; the Convention against Discrimination in Education; Optional Protocol to the Convention against Torture and Other Cruel, Inhuman or Degrading Convention against corruption. The provisions of the acts mentioned were held especially in cases where the object of the constitutional dispute was related to: the principle of equality and non-discrimination; free access to justice; personal liberty; the principle of presumption of innocence; the right to personal, family and private life; freedom of assembly and association; the right to education ${ }^{7}$.

In the Republic of Moldova, the Constitutional Court has the power to intervene in the process of acceptance of international law into domestic legal order, ensuring consistency between the provisions of international treaties and those of the Constitution. This prerogative is enshrined in Article 135 para. (1) letter a) of the Constitution, which provides that the Constitutional Court shall rule, upon referral, the constitutional review of international treaties to which the Republic of Moldova is a party.

It is worth mentioning the jurisprudential developments concerning the moment when the Constitutional Court intervenes in the process of constitutional review on the compatibility between international agreements and domestic legal order. There was no uniform approach in this area in the case-law and doctrine of the Republic of Moldova. Thus, the dominant view in the doctrine was based on the concept that the constitutional review of international treaties, as well as of other acts subject to review, can be carried out only a posteriori, after their entry into force ${ }^{8}$.

\footnotetext{
${ }^{7}$ Report of the Constitutional Court of the Republic of Moldova at the XVIl Congress of the Conference of the European Constitutional Courts (Vienna, May 2014), pp. 3-5.

${ }^{8} \mathrm{~V}$. Zaporojan, Ratification of the international treaties in the Republic of Moldova: constitutional aspects, in "Constitutional Justice in the Republic of Moldova", 2011, no. 1, p. 14; The Constitution of the Republic of Moldova: commentary, Chișinău, Arc, 2012, p. 57.
} 
As concerns the case-law, such issue has been addressed in Decision no. 5 of 24 September $2002^{9}$. In this case, the Constitutional Court suspended the process of constitutional review on certain provisions of the Treaty between the Republic of Moldova and Ukraine regarding the state border and of the Addendum Protocol to the Treaty on the ground that, at the moment of examination of the referral, the treaty had already entered in force. Invoking the principle of international law regarding the fulfilment of international agreements by the state, the Court noted in its decision that "the exercise of the constitutional review of this treaty would be contrary to the international principles on the execution of treaties in good faith, which would harm the credibility of the Republic of Moldova as a partner in the relations established by international treaties and delay or even cease the development of such interstate and intergovernmental relations of the country". The Constitutional Court underlined that "once in force, the treaty falls under international law principle of pacta sunt servanda, becoming enforceable".

This approach has resulted in a crisis situation because, on the one hand, according to the dominant conception, the Court had the competence to examine the international treaty only after its entry into force and, on the other hand, the Court recognized that, once entered into force, the treaty becomes enforceable, so that the constitutional review could not be exercised.

It should be noted that, in its case-law, the Constitutional Court did not maintain the consistent position of the exclusively a posteriori review of the treaties, as it examined in a case the constitutionality of a treaty which, at the time, was signed but it had not yet been ratified by Parliament ${ }^{10}$.

The issue concerned was also discussed in a recent case ${ }^{11}$ when the Court gave a new solution. The competence of the Constitutional Court on the fulfilment of the constitutional review of international treaties is carried out, according to the Constitutional Court, between the expression of consent by the Republic of Moldova to be connected internationally by the treaty (by signature, the exchange of instruments constituting a treaty, ratification, acceptance, approval or accession to it, or by any other means agreed of formal confirmation of consent) and the entry into force of the treaty through the fulfilment of procedures required by law. Thus, when the Constitutional Court ascertains the unconstitutionality of an international treaty to which the Republic of Moldova became a part, the national public authorities will not fulfil the legal procedures for the entry into force of the treaty, in compliance with the provisions of

\footnotetext{
${ }^{9}$ Official Gazette of the Republic of Moldova no. 137-138/25 of 10 October 2002.

${ }^{10}$ Decision no. 22 of 2 October 2007 for the constitutional review of certain provisions of the Statute of the International Criminal Courts, Official Gazette no. 161-164/19 of 12 October 2007.

11 The Constitutional Court's Decision no. 17 of 07 November 2013 rejecting the referral no. 35a /2013 for the constitutional review of certain acts on the Agreement between the Government of the Republic of Moldova and the Government of Romania on the cooperation in the military field, Official Gazette no. 312-314 of 31 December 2013.
} 
Article 22 para. (2) of Law no. 595-XIV of 24 September 1999 on international treaties of the Republic of Moldova.

The issue regarding the interaction of the Constitution with the international law has been also addressed in the Constitutional Court's Decision no. 24 of 9 October 2014 on the constitutional review of the Association Agreement between the Republic of Moldova, on the one hand, and the European Union and the European Atomic Energy Community and its Member States, on the other hand, and of Law no. 112 of 2 July 2014 on the ratification of the Association Agreement ${ }^{12}$. In particular, the Court addressed the issue of correlation between two constitutional principles that are the principle of sovereignty and for the compliance with the international law.

The Court based its reasoning on the argument that the right of the state to undertake the international agreements is an element of state sovereignty. The constitutional sovereignty of the Republic of Moldova is manifested externally by establishing cooperation relations with other states and international entities. Mainly, such relations are established on the basis of international treaties, the latter being regarded as a coordination means of the agreements of various countries, which results from the exercise of sovereignty.

In that context, the Court underlined that the delegation of certain powers to international authorities by concluding treaties does not entail the renunciation to sovereignty. Such treaties are agreements by which the holder of sovereignty shall delegate certain powers to another authority. The transfer of powers of the state, transfer arising from the free will of the sovereign state and allowing the further exercise of powers with the participation of the sovereign state, in a manner agreed in advance and subject to control, is not a conceptual weakening of sovereignty, but, a contrario, it can result in its strengthening within the integrated joint actions.

As regards the compatibility of the Association Agreement with the Constitution of the Republic of Moldova, having examined the provision of the agreement, the Court found that it promotes political association and economic integration between the Republic of Moldova and the European Union based on common values such as the observance and promotion of the principles of sovereignty and territorial integrity, of the inviolability of borders and of the independence of the Republic of Moldova, the democracy, the rule of law and the compliance with the fundamental human rights and freedoms.

Similarly, the Court considered it necessary to mention that the orientation of the Republic of Moldova towards the European space of democratic value is inseparable from other international agreements stemming from the membership of international organizations. The

12 Official Gazette no. 333-338 of 7 November 2014. 
compliance with the international obligations assumed by their own will is a legal tradition and a constitutional principle, as an inseparable part of the rule of law.

\section{Acceptance of the case-law of the ECHR}

\section{within the constitutional review}

Although the national constitutional law contains no express regulations which would require the application of the case-law of the European Court of Human Rights in the national constitutional case-law, since the former is integrated in the provisions of the European Convention, the need to take it into consideration arises from the provisions of Article 4 para. (2) of the Constitution, according to which the constitutional provisions on human rights and freedoms are interpreted and applied in accordance with the Universal Declaration of Human Rights, with the covenants and other treaties to which the Republic of Moldova is a party.

In the case-law of the Constitutional Court, the decisions which were given solutions based both on the provisions of the Convention and on the case-law of the European Court, besides the constitutional rules, are the most numerous, in areas such as the infringement of the right to property, the principles of equality and non-discrimination, the right to defence, the free access to justice, the fair trial settled within a reasonable time, freedom of assembly and association ${ }^{13}$.

It is worth mentioning that for the fulfilment of the constitutionality review of certain legal provisions concerning the fundamental rights and freedoms of the individual, the Constitutional Court of the Republic of Moldova, by the decisions pronounced, confirms the principle of direct applicability of the European Convention and of the case-law of the High Court and essentially contributes to the effective integration of the European Convention throughout the internal regulations on human rights. Inter alia, by Decision no. 19 of 18 December 2012, the Constitutional Court underlined: "[...] although the settlement of real disputes between real individuals is the exclusive power of the courts, and they are solely able to quantify in concreto the effects of the application of the rule to the actual situation taken to court, by reporting the impugned rules both to the constitutional provisions and to the provisions of the European Convention, the Constitutional Court rules on the quality of legal rules to observe in abstracto the provisions of the Constitution and of the European Convention, taking into account, at the same time, the potential effects or the risks posed by it in relation to the addressees of the rule" 14 .

\footnotetext{
${ }^{13}$ Report of the Constitutional Court of the Republic of Moldova at the XV Congress of the Conference of the European Constitutional Courts (Vienna, May 2014), p. 6.

${ }^{14}$ Official Gazette no. 18-21 of 25 January 2013.
}

REVISTA DE DREPT CONSTITUTZIONAL 
The continuous development of European Court determined the Constitutional Court, in certain situations, to reconsider its own case-law. A relevant example is Decision no. 10 of 16 April 2010 cited above. One argument for the revision of the the previous decision of the Constitutional Court determined the amendment of the case-law of the European Court exposed in the Case Pellegrin vs. France by judgment on the case Vilho Eskelinen and Others vs. Finland, directly examined by the Grand Chamber. In its decision, the Constitutional Court stated the following reasons: [...] the revision of the Decision no. 16 of 28 May 1998 is dictated both by the Constitution and by the law of the case-law of the ECHR and the new need of the Republic of Moldova to meet the "Eskelinen test". As concerns such interpretation, the domestic and international law represents a whole, a unitary structure in the Republic of Moldova. Therefore, the category of normative acts also includes the international rules to which the Republic of Moldova is a party. Since the case-law of the ECHR is part of the accessory right to the international treaty (soft law) by the interpretation of the European Convention, it becomes part of the domestic law. Thus, the amendment to the case-law of the ECHR is tantamount to the amendments to normative acts, allowing the Constitutional Court, under Article 72 of the Code of Constitutional Jurisdiction, to reconsider its own case-law".

\section{The dialogue with other constitutional courts}

The doctrine stated rightly that "[...] the enhancing of the dialogue between the constitutional courts and the strengthening of their relations [...] result in a phenomenon of emergence towards the common constitutional values, but also an extension of institutionalization of the constitutional review, reconsiderations regarding the powers of the constitutional courts, reconsiderations and improvements of the acts of the constitutional court $[\ldots]^{\prime 15}$.

The transnational judicial dialogue of the constitutional court is conducted in different ways: by using the precedents of other constitutional courts; by the exchanging experience in the constitutional justice field within conferences, symposiums and other meetings; within bilateral relations with other constitutional courts; within specialized international bodies.

It is reasonable that a constitutional court of a State shall investigate the constitutional case-law of other countries, which already have faced similar issues, and, taking into account the circumstances of the case, the similarity of legal institutions which are the object of the constitutional review, analyze and possibly apply such exposed arguments in the decision of the court concerned. Therefore, for the examination of the

15 T. Toader, M. Safta, The Dialogue of the constitutional judges, Universul Juridic Publishing House, Bucharest, 2015, p. 138. 
pending cases, it should be carefully studied the relevant legislation and constitutional case-law of other states, it should be investigated and analyzed the solutions given by the foreign constitutional courts on issues similar to those which the Court examines. The arguments mentioned in the decisions of the foreign constitutional courts are quoted in the decisions of the Constitutional Court of the Republic of Moldova in order to support its reasoning to strengthen the position of the Court or to illustrate the importance of the issue examined ${ }^{16}$.

The constitutional justice is also developed through the information exchanges made at international conferences, meetings, roundtables and working meetings of judges and employees of the Constitutional Court, which take place on a regular basis.

In order to increase and strengthen the cooperation relations in the field of constitutional justice and given its complexity and dynamism in a state of law, the Constitutional Court of the Republic of Moldova signed protocols and memoranda of cooperation with the Constitutional Court of Romania (11 December 2001), the Constitutional Court of Ukraine (5 June 2002), the Constitutional Court of the Russian Federation (1 November 2005), the Constitutional Court of the Azerbaijan Republic (14 July 2010), the Constitutional Court of Georgia (22 September 2012). As regards the multilateral relations, we should mention that the Constitutional Court of the Republic of Moldova maintains and strengthens the cooperative relations with similar institutions at European and global level as a full member of the following international bodies: the European Commission for Democracy through Law of the Council of Europe (Venice Commission), the Association of Constitutional Courts using the French Language (ACCPUF), the Conference of European Constitutional Courts (CCCE) and the World Conference on Constitutional Justice $(\mathrm{CMJC})^{17}$.

\section{Constitutional Court in relation to public authorities}

The doctrine noted that, since the Constitutional Court is called upon to ensure the compliance with the constitutional rules by each of the three powers, it has a position of arbitrator in relation to them ${ }^{18}$. In the Republic of Moldova, the Constitutional Court is not expressly empowered to settle legal disputes of a constitutional nature between public authorities, such as Romania, but, having the exclusive constitutional power to ensure the implementation of the principle of separation of powers, the Court also examines the impugned normative acts in this regard. In a number of cases, the Constitutional Court has found that public authorities, representatives of the state power, assumes duties and

\footnotetext{
${ }^{16}$ Report of the Constitutional Court of the Republic of Moldova at the XVII Congress of the Conference of the European Constitutional Courts (Viena, May 2014), p. 15.

17 Ibidem, p. 18.

${ }^{18}$ I. Deleanu, Constitutional law and political institutions, vol. I, Lumina Lex Publishing House, Bucharest, 1996, p. 285.
} 
powers which, under the Constitution, do not belong to it or exceed them or, on the contrary, they fail to meet certain acts falling under their obligations.

As concerns the exceeding of the limits of their constitutional powers by certain authority, an eloquent case in this regard was the one on the powers of the resigning Government $^{19}$. In this case, the Court held that, in accordance with the provisions of the Constitution, a resigning Government continues to manage the public affairs while waiting for a new Plenipotentiary Government. The management of public affairs refers to the current daily decisions of the Government that are needed for the uninterrupted operation of the public service. Conferring certain excessive powers upon a resigning Government constitutes a possible danger for the exercise of democracy. Therefore, the margin of the manoeuvre for the resigning Government is limited on the appointment of officials, on the implementation of new reforms and other important actions that remain suspended as the Government does not have a full term of office.

The Court held, inter alia, in a case on the budget process, concerning the omissions admitted by certain authorities in the exercise of the powers conferred by the Constitution $^{20}$. In the present case, the Court held the provisions of the Basic Law, establishing the obligation of the prior consent of the Government regarding the amendments or legislative proposals which involve the increase or decrease of expenses, income or loans, as an essential condition on which the legislature cannot derogate in the process for the approval of the national public budget, a non-compliance which constitutes a violation of the procedure set forth in the Constitution, regarding lawmaking process in budgetary matters. The Government can neither waive a right/a constitutional obligation nor express acceptance or refusal concerning certain legislative proposals or amendments with budgetary impact.

As noted rightly, the exercise of its power to settle disputes between authorities often requires the involvement in delicate areas, disputes difficult to be judged, egos difficult to be met $^{21}$. Constitutional judges should express an unquestionable independence and impartiality, prudence and tact, as well as a rich constitutional imagination $^{22}$.

Recently, the Constitutional Court of the Republic of Moldova has faced some trials of interventions of the legislature in the status of the constitutional court likely to affect its independence, interventions dictated by certain political interests. Thus, the Court

\footnotetext{
${ }^{19}$ Decision no. 7 of 18 May 2013 on the constitutional review of certain provisions of Law no. 64-XII of 31 May 1990 on the Government, for the drafting of Laws no. 107 and 110 of 3 May 2013 and of the Decrees of the President of the Republic of Moldova no. 634-VII and 635-VII of 16 May 2013 and of the Resolution of the Government no. 364 of 16 May 2013, Official Gazette no. 173-176/23 of 9 August 2013.

${ }^{20}$ Decision no. 2 of 28 January 2014 for the constitutional review of certain fiscal provisions relating to local taxes, Official Gazette no. 80-85/10 of 4 April 2014.

${ }^{21}$ Constitutional justice: powers and relations with other public authorities. The national report for the XVl Congres of the Conference of the European Constitutional Courts, submitted by the Constitutional Court of Romania, available at //http://www.confeuconstco.org/reports/rep-xv/ROMANIA\%20ro.pdf.

${ }^{22}$ M. Constantinescu, A. Iorgovan, I. Muraru, The revision of the Constitution of Romania, Rosetti Publishing House, Bucharest, 2003, p. 86.
} 
ascertained the unconstitutionality of the amendments to the organic law governing the constitutional court, which provided the cessation of terms of office of the judges of the Constitutional Court by Parliament on grounds of "loss of confidence". The Court described such attempt as impermissible interference in the work of the Constitutional Court, i.e. a violation of the principle of independence, contrary to the principles of immovability and independence of its judges. Both the Constitution and the Law on the Constitutional Court regulate important principles and guarantees of independence and neutrality of the judges of the Constitutional Court likely to enable them the objective exercise of the judgment, as, under Article 134 para. (2) of the Constitution, the Court itself is "independent in relation to any other public authority" and obeys only the Constitution. The Constitutional Court has the power to verify the work of Parliament. The judges of the Court shall obey the need of "confidence" of Parliament which is clearly contrary to the purpose itself of a Constitutional Court. Therefore, the responsibility of the judges of the Constitutional Court shall be inadmissible before Parliament, whose activity is verified by the Court ${ }^{23}$.

\section{The effectiveness of the constitutional justice.}

\section{Methods of implementation}

The effects of erga omnes of the decisions of the Constitutional Court include the constitutional obligation of all authorities to implement faithfully all decisions on the actual situations where the rules declared unconstitutional are covered. The Constitution and the organic laws regulating the constitutional competence contain provisions aimed at ensuring the effectiveness of the decisions of the Constitutional Court. Thus, according to the law, the Government shall submit to Parliament, within 3 months as of the date of publication of the decision of the Constitutional Court, a draft law amending and supplementing the normative act or parts of it declared unconstitutional. The draft law shall be considered by Parliament as a priority. Similarly, the legal rule stipulates that the President of the Republic of Moldova or the Government shall amend and supplement or repeal, no later than two months as of the date of publication of the decision of the Constitutional Court, the act or certain parts of it declared unconstitutional and, if necessary, it shall issue or adopt a new act.

If, during the examination of the case, the Constitutional Court finds certain shortcomings in legislation, due to the non-compliance with certain provisions of the Constitution, it attracts the attention of the bodies concerned, through a letter, on such shortcomings. The letters addressed to the Constitutional Court are to be examined by

\footnotetext{
${ }^{23}$ Decision no. 18 of 2 June 2014, Official Gazette no. 256-260 of 29 August 2014.
} 
the court concerned, which, within 3 months, informs the Constitutional Court about the results of the examination.

Despite these regulations, the Court confirms the lack of an immediate reaction within the time provided by the law, which causes a delay in the execution of several decisions and the failure to examine the letters creates situations that maintains the lacks in legislation and affects the quality of implementation of laws. The absence of the legislature's reaction to the decision of the Court, the delays in the settlement of such problems or the partial elimination of such lacks are regarded as anomalies of the legal system and their existence is considered inadmissible and intolerable ${ }^{24}$.

The legislature must eliminate the reported shortcomings. The unconstitutional "void" occurred in an area or an issue of law, the tolerance of a law or of a defective normative act indicates that Parliament, as a political institution empowered by the Constitution with the power of lawmaking, does not fully accomplish its constitutional mission conferred upon it. The obligation of the legislature to eliminate the legal shortcomings arises from the principles of the rule of law and the principle of separation of powers ${ }^{25}$.

The decision of the Constitutional Court must include a dual legal effect. Firstly, it should be a guarantee for the protection of the objective right of each individual and, secondly, it should become a source of law for the legislature and executive, playing a guiding role in the development of law. Only together such aspects can ensure the supremacy of the Constitution by ensuring the constitutionality of normative acts ${ }^{26}$.

\section{Prospects of constitutional justice in the Republic of Moldova}

In Europe, two models for the organization of constitutional jurisdiction were pointed out in terms of citizens' access to constitutional justice. The first, also chosen by the framer in the Republic of Moldova, enshrines the indirect access of citizens to the Constitutional Court for the referral of the normative acts that violate their rights, through ordinary courts and public authorities, being entitled to referral to the Constitutional Court. The second model accepts the direct public access to constitutional court, by way of individual appeal, which appears in various countries under various forms and procedures.

\footnotetext{
24 The report on the exercise of the constitutional justice in 2013, Chișinău, Arc Publishing House, Republic of Moldova, 2014, p. 140.

${ }^{25}$ General report of the XIV Congress of the Conference of the European Constitutional Courts on the issues relating to the legislative inaction in the constitutional justice (July 2008), available at http://www.venice. coe.int/files/Bulletin/SpecBull-legislative-omission-f.pdf.

26 Report on the exercise of the constitutional justice in 2014, available at http://www.constcourt.md/ public/files/file/Actele\%20Curtii/acte_2015/Raport_CC_2014.ro.pdf.
} 
The issue regarding the opportunity to introduce the individual constitutional appeal within the perspectives of constitutional justice in the Republic of Moldova is debated today, probably the most by doctrinaires and experts ${ }^{27}$.

Those who advocate for changing the paradigm of organization of the constitutional jurisdiction by establishing the citizens' direct public access to the Constitutional Court invoke the deficiencies of the existing system. Indeed, according to the regulations in force, the person, in his/her approach to challenge the normative act which violates his/her rights, is dependent on the will of the subject entitled to referral or, in case of the exception of unconstitutionality, of the court's will. Thus, in light of the provisions of Article 135 para. (1) letter g) of the Constitution, Article 7 para. (3) of the Code of Criminal Procedure and of Article 12/1 of the Code of Civil Procedure, the unconstitutionality of a law may be invoked by the Supreme Court of Justice at the time of the dispense of justice before the court of common law by a person who is a party to the trial. Although the law apparently provides litigants the possibility to refer or not to the Constitutional Court, in reality, the decision to refer or not to the constitutional court belongs, firstly, to the court which, in essence, adjudicates on the admissibility of the application, and then to the Supreme Court of Justice, which, in fact, takes the decision to refer or not to the Constitutional Court. This situation makes the concept of exception of unconstitutionality to lose its effectiveness. This is the root for the low number of settlements of the exceptions of unconstitutionality in the case-law of the constitutional court (for example, in comparison with Romania, where most of the cases examined by the constitutional court concern the exceptions of unconstitutionality). Thus, from 36 decisions of the Constitutional Court of the Republic of Moldova, rendered en in 2013, only 3 were concerned the settlement of the exceptions of unconstitutionality.

In light of the above, it is imperative required the need for amendments, both to the Constitution and to organic laws, in order to improve the concept of the exception of unconstitutionality (see infra). Similarly, it is necessary to make this concept better known by legal advisers, both judges and lawyers (via publications, continuing education system, conferences, seminars etc.) in order to ensure a more extensive implementation of this concept in the judicial activity.

Since the concept concerned will work effectively beginning with the stage of trial on the merits, we consider that, in the Republic of Moldova, the access to the Constitutional Court regarding the exception of unconstitutionality will be an effective means of protection for the constitutional rights of individuals and, at the same, an effective method of constitutional review for the normative acts relating to the fundamental rights and freedoms.

\footnotetext{
27 V. Zaporojan, The constitutional application and the exception of unconstitutionality in comparative aspect, in "Constitutional Justice in the Republic of Moldova", 2008, no. 1, p. 25; D. Pulbere, Certain reasonings on the citizens' access to the Constitutional Court by the subjects of law with right to referral and the need for the implementation of the constitutional application, in “Constitutional Justice”, 2011, no. 3, p. 13.
} 


\section{Conclusions}

If the legitimacy of an institution lies in the collective confidence in its social value ${ }^{28}$, despite the criticism to certain decisions of the Constitutional Court (which is natural in a democratic society), the constitutional court, throughout its existence, gained such collective confidence, representing a true pillar for the support of the state and democracy, and it sees to ensure the supremacy of the Constitution, being the safest instrument to protect the fundamental rights and freedoms of citizens. However, the Constitutional Court contributes to the proper functioning of public authorities by ensuring the fulfilment of constitutional principle of separation, balance, cooperation and mutual review of state powers. Similarly, by exercising the constitutional review, the Court plays a vital role in the lawmaking process and contributes to the improvement of the law and to the removal of the existing deficiencies.

Given the recent developments in the political and social life of our country, as well as the conditions in which the Constitutional Court fulfilled its power to find effective constitutional solutions for the issues brought before it, we consider it imperative that the constitutional court be subject to certain constitutional and legislative adjustments that should better delimit its role, its powers should be better defined, so as the institution could operate under conditions that would exclude influences and interferences which are not allowed, and the powers of the constitutional judges, the impartiality, the objectivity, but also their professional abilities would never be questioned.

As noted rightly, "the problems which the Constitutional Court of the Republic of Moldova has faced, namely the establishment by law of the possibility to dismiss judges of the Constitutional Court for the "loss of confidence" of Parliament and the limitation of the powers of the constitutional court, underline the need for an institutional strengthening, which can be achieved including by a clear indication or enhance of the powers of this Court" ${ }^{29}$.

Summarizing the recommendations made by experts ${ }^{30}$, the views of the doctrinaires and the conclusions required, based on the analysis of the jurisprudential development of the Court and the issues identified in the judicial activity, we would like to emphasize a series of proposals for de lege ferenda.

1. We consider necessary to regulate by law the procedure for the appointment of the constitutional judges on the basis of uniform, fair, objective and transparent criteria, for the selection of candidates, so as the impartiality, neutrality, and their professional

\footnotetext{
${ }^{28}$ D. Rousseau, Droit du contentieux constitutionnel, Montchrestien, Paris, 2006, p. 83.

${ }^{29}$ The analysis of the component, of the selection criteria and of the work of the judges of the Constitutional Court of the Republic of Moldova. The view of T. Toader, expert, member of the Venice Commission, Judge of the Constitutional Court of Romania within the Study "Strengthening the role of the Constitutional Court of the Republic of Moldova", submitted in Chișinău, 17 July 2015.

${ }^{30}$ In this regard, see Study "Strengthening the role of the Constitutional Court of the Republic of Moldova”, conducted by V. Catană, M. Granat, T. Tanchev and T. Toader, submitted at Chișinău, 17 July 2015.
} 
abilities shall not be questioned and also in order to eliminate the political bias in the appointment of the constitutional judges.

2. We advocate for changing the term of office of the constitutional judge so as to be elected for a single term of office of nine years, with the renewal of the members of the Court every three years, in proportion to the number of judges appointed by each authority.

3. Regarding the numerical composition of the Court, taking into account the need to ensure the effectiveness of the Court, especially to avoid the blockage in the decision-making process, we consider it useful to set an odd number of judges, for example, seven.

4. Given the recent jurisprudential solutions, we consider necessary to enshrine the expressis verbis in the Constitution and in the infra-constitutional laws of the Constitutional Court's power of constitutional review of laws before their entry into force.

5. Given the problems faced in the settlement of the disputes which aim at ensuring the compliance of the international agreements of the Republic of Moldova with the Constitution, we consider necessary to regulate, in the Constitution and in the infraconstitutional laws, the phase when the constitutional court can exercise such power.

6. We advocate for enshrining in the Constitution and in the organic laws the mandatory approval of constitutional laws by the Constitutional Court, before and also after their adoption in Parliament ${ }^{31}$.

7. Regarding the exception of unconstitutionality, it is proposed to make amendments to the constitutional and infra-constitutional rules, so that the exception to be raised before the Constitutional Court directly by the court of first instance; its admissibility shall be decided by the Constitutional Court and the advocacy of the exception to be supported by the party who invokes it.

8. Given that the Court shall examine issues of law and not disputes on individual rights, the procedure must be written and the parties shall be invited to plead only when the Court considers it necessary.

\footnotetext{
31 On 5 July 2000, XIV Legislative Parliament adopted a new law for the revision of the Constitution, other than that aproved by the Constitutional Court, by which, inter alia, the mechanism for the election of the President of the state was amended, resulting several times in crisis situation.
} 